\title{
GENERAL EDITOR'S INTRODUCTION
}

Most societies clearly reveal both their moral norms and their political ideologies through their efforts to acculturate the young. While this can be an area of contention as much as of agreement, there is a particularly powerful urge to consensus in the training of youth, since their exposure to too much disagreement can seem to have socially disruptive or politically subversive results. It is indeed one of the notable characteristics of the late nineteenth and early twentieth centuries that many European countries, their imperial territories, and rapidly Europeanising imitators like Japan, established a powerful zone of intellectual, ideological and moral convergence in the projection of state power and collective objectives to children.

A variety of media were bent to these ends: school textbooks, juvenile journals, a host of adventure stories and hagiographical biographies, religious and youth organisations, some aspects of the theatre and later the cinema, as well as advertising and visual aspects of collectable ephemera. In some countries, many of these materials were subjected to direct state control (this was true of Japan for example), but in those where central governmental direction was relatively light (as in Britain), the consensus seems to have been achieved by voluntarist means.

In the past quarter-century or so there has been a growing awareness of the value of school texts in exposing the dominant ideology and objectives of those concerned with youth training, and thus of the elites most concerned with creating a degree of social conformity. There have also been studies of much juvenile literature as revealing the fantasies and attitudes of their adult creators. Kathryn Castle succeeds in bringing both of these together. Her focus is specifically upon representations of other societies in British texts, both those designed for instruction in schools and for entertainment in the home. Her 'others' are mainly those who were rendered strangely and deceptively familiar through imperial rule or commercial connection. By expanding her horizons to Africa, India and China - with many allusions to other non-European peoples - she makes a notably wideranging contribution to the discussion of representations of others that has been such a significant aspect of much recent scholarship.

John M. MacKenzie 